\title{
Toxicological and Biochemical Effects of Four Bioactive Secondary Plant Metabolites Isolated from Simmondsia Chinensis (Link) and Artemisia judaica L. on White Albino Rats
}

\author{
Moustafa A. Abbassy ${ }^{1}$, Samir A. M. Abdelgaleil ${ }^{2, *}$, Abdel-Salam H. Belal ${ }^{1}$, Mona A. Abdel Rasoul ${ }^{1}$
}

\begin{abstract}
Four pesticidal botanicals were isolated (two from, Simmondsia chinensis and two from Artemisia judaica) and identified as simmondsin, simmondsin 2 'ferulate, piperitone and trans-ethyl cinnamate, respectively. Oral administration of single doses each of 250 or $500 \mathrm{mg} / \mathrm{kg}$ from each compound did not show any signs of toxicity or mortality to male albino rats after two days of treatment. The in vivo effects of these compounds on activities of alkaline phosphatase (ALP), gamma-glutamyl transferase (GGT), lactate dehydrogenase (LDH) and creatinine phosphokinase (CPK) in the serum of treated rats and concentrations of testosterone, follicle stimulation hormone (FSH) and triiodothyronine hormone (T3) were evaluated. Simmondsin 2 '-ferulate displayed significant decrease in the activity of ALP enzymes at the two tested doses. Simmondsin caused decrease in the activity of the enzymes at $250 \mathrm{mg} / \mathrm{kg}$ and increase in the enzymes activity at 500 $\mathrm{mg} / \mathrm{kg}$. Piperitone and trans-ethyl cinnamate increased the activity of the enzymes at two tested doses. The tested compounds showed no significant effect on the activity of GGT except for trans-ethyl cinnamate at $500 \mathrm{mg} / \mathrm{kg}$. Simmondsin and simmondsin 2'-ferulate displayed significant decrease in the activity of both LDH and CPK, while piperitone and trans-ethyl cinnamate caused increase in the activity of these enzymes. The tested compounds lowered the concentration of FSH. Simmondsin and simmondsin 2 -ferulate decreased the concentration of T3 and testosterone. Piperitone and trans-ethyl cinnamate increased the concentration of these enzymes.
\end{abstract}

Keywords: Biochemical effects; simmondsin; simmondsin 2 ferulate; piperitone; trans-ethyl cinnamate; white albino rats; enzymes; hormones.

\section{INTRODUCTION}

Natural products have enormous potential to inspire and influence modern chemical research of agriculture and medicine. The increasing interest in the possible application of secondary metabolites to pest management has directed the investigation toward search for new sources of biologically active natural products with low mammalian toxicity, lack of neurotoxic mode of action, low persistence in the

\footnotetext{
${ }^{1}$ Department of Pest Control and Environmental Protection, Faculty of Agricultur(Damanhour),Alexandria University,Damanhour, Egypt

${ }^{2}$ Department of Pesticide Chemistry, Faculty of Agriculture,

21545-El-Shatby, Alexandria University, Alexandria, Egypt

*Correspondence author. Fax: +20-3-592-0067; Tel.: +20-3-584-7175.

E-mail address: samir1969us@ yahoo.com (S. Abdelgaleil)

Received September 9, 2008, Accepted September25, 2008
}

environment and biodegradability, as well as delaying the development of pest resistance. Recent studies on this field showed the importance of natural chemicals as a possible source of non-phytotoxic, systemic and easily biodegradable alternative pesticides (Jacobson, 1989; Singh et al., 1997; Gonzalez-Coloma et al. 1997).

In our previous studies, simmondsin and simmondsin 2`ferulate isolated from Simmondsia chinensis, a semi evergreen shrub, and piperitone and trans-ethyl cinnamate isolated from Artemisia judaica, a perennial fragrant shrub, showed promising insecticidal and antifeedant activities against the third instar larvae of the Egyptian cotton leafworm, Spodoptera littoralis (Abbassy et al., 2006 and 2007). In addition, these compounds revealed antifungal and molluscicidal activities against some of plant pathogenic fungi and a land snail Eobania vermiculata (Abbassy et al., 2007, Abdelgaleil et al., 2007). This strong pesticidal potential of the isolated compounds encouraged us to study the side effects of these compounds on mammals. Therefore, the present study describes the toxic effects of the isolated compounds; simmondsin, simmondsin 2 ferulate, piperitone and trans-ethyl cinnamate on male rats and their in vivo effects on the activities of alkaline phosphatase, gamma-glutamyl transferase, lactate dehydrogenase and creatinine phosphokinase in the serum of treated rats and on the concentrations of testosterone, follicle stimulation hormone and triiodothyronine hormone.

\section{MATERIALS AND METHODS}

\section{Plant materials}

Seeds of Simmondsia chinensis (Link) Schneider (jojoba plant) and aerial parts of Artemisia judaica (L.) (Shih plant) were collected from Al-Bostan Region and Sinai Peninsula, respectively.

\section{Instruments}

${ }^{1} \mathrm{H}$ and ${ }^{13} \mathrm{C}$ NMR spectra were recorded at $500 \mathrm{MHz}$ and $125 \mathrm{MHz}$, respectively, on a JEOL JNM ECD 500 Spectrometer in $\mathrm{CDCl}_{3}$. IR spectra were performed with 
Perkin Elmer 1430 Ratio Recording Infrared Spectrometer in $\mathrm{KBr}$ disks. UV spectra were measured with HE $\lambda$ IOS $\alpha$ UV-VL Spectrophotometer V4.60 in methanol.

3. Extraction, isolation and identification of the active principles from $S$. chinensis and $A$. judaica

The chloroform extract of $S$. chinensis seeds (45.4 g) was subjected to silica gel column chromatography eluted by chloroform, $10 \%$ methanol/chloroform, $20 \%$ methanol/chloroform and methanol solvent systems. Thirty fractions of $200 \mathrm{ml}$ were collected and pooled to two main fractions based on their TLC profiles. Fraction 1 (3.4 g) was further purified by silica gel column chromatography using $10 \%$ chloroform/methanol solvent system to give $2.1 \mathrm{~g}$ of a compound simmondsin 2 -ferulate (2), (Figure 1). Similar purification of the second fraction $(7.3 \mathrm{~g})$ followed by recrystallization from acetone/chloroform (1:4) gave $5.4 \mathrm{~g}$ pure prisms of a compound which identified as simmondsin (1).

Simmondsin (1): $\delta{ }^{1} \mathrm{H}$ NMR $1.68(1 \mathrm{H}, \mathrm{dt}, \mathrm{J}=14.5$ and $3.9 \mathrm{~Hz}, \mathrm{H}-6 \mathrm{a}), 2.48(1 \mathrm{H}, \mathrm{dt}, \mathrm{J}=15.3$ and $3.9 \mathrm{~Hz}, \mathrm{H}-$ 6b) $3.13(1 \mathrm{H}, \mathrm{dd}, 9.2$ and $3.1 \mathrm{~Hz} \mathrm{H}-2), 3.22(1 \mathrm{H}, \mathrm{m} \mathrm{H}-$ 4), $\left.3.29(1 \mathrm{H}, \mathrm{t}, \mathrm{J}=8.4 \mathrm{~Hz}, \mathrm{H}-5)^{`}\right), 3.32(1 \mathrm{H}, \mathrm{t}, \mathrm{J}=9.2$, H-4`), $3.36\left(1 \mathrm{H}, \mathrm{t}, \mathrm{J}=8.6 \mathrm{~Hz}, \mathrm{H}-3^{`}\right), 3.43(3 \mathrm{H}, \mathrm{s}, 5-$ $\left.\mathrm{OCH}_{3}\right), 3.45\left(3 \mathrm{H}, \mathrm{s}, 4-\mathrm{OCH}_{3}\right), 3.64(1 \mathrm{H}, \mathrm{dd}, \mathrm{J}=12.3$ and $5.4 \mathrm{~Hz}, \mathrm{H}-6 \mathrm{a}), 3.81\left(1 \mathrm{H}, \mathrm{brd}, \mathrm{J}=12.2 \mathrm{~Hz}, \mathrm{H}-6{ }^{`} \mathrm{~b}\right)$,

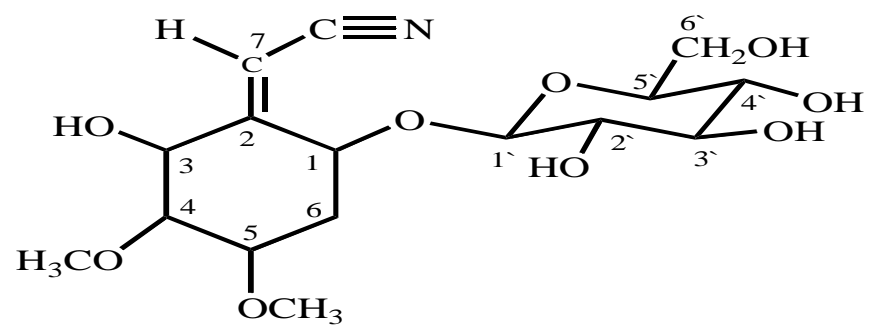

Simmondsin (1)

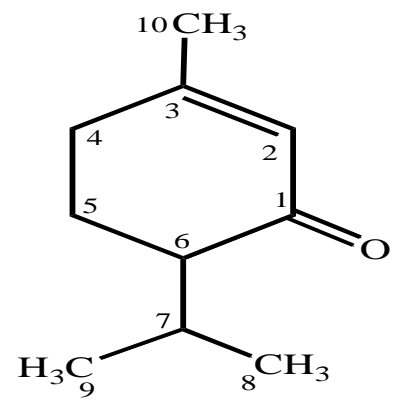

Piperitone (3)
$3.90(1 \mathrm{H}, \mathrm{q}, \mathrm{J}=3.7 \mathrm{~Hz}, \mathrm{H}-5), 4.37(1 \mathrm{H}, \mathrm{d}, \mathrm{J}=8.4 \mathrm{~Hz}$, $\left.\mathrm{H}^{`}\right), 4.71(1 \mathrm{H}$, brd, $\mathrm{J}=8.4, \mathrm{H}-3), 4.86(1 \mathrm{H}, \mathrm{t}, \mathrm{J}=3.9$, $\mathrm{H}-1)$ and $5.69(1 \mathrm{H}, \mathrm{s}, \mathrm{H}-7)$.

Simmondsin 2'-ferulate (2): $\delta{ }^{1} \mathrm{H}$ NMR $1.47(1 \mathrm{H}$, $\mathrm{d}, \mathrm{J}=12.3 \mathrm{~Hz}, \mathrm{H}-6 \mathrm{a}), 2.39(1 \mathrm{H}, \mathrm{d}, \mathrm{J}=14.5 \mathrm{~Hz}, \mathrm{H}-6 \mathrm{~b})$ $3.00(1 \mathrm{H}, \mathrm{dd}, 10.0$ and $3.3 \mathrm{~Hz}, \mathrm{H}-4), 3.23(3 \mathrm{H}, \mathrm{s}, 5-$ $\left.\mathrm{OCH}_{3}\right), 3.35(1 \mathrm{H}, \mathrm{m} \mathrm{H}-5), 3.37\left(3 \mathrm{H}, \mathrm{s}, 4-\mathrm{OCH}_{3}\right), 3.45$ $\left(1 \mathrm{H}, \mathrm{dd}, \mathrm{J}=19.1\right.$ and 9.9, $\left.\mathrm{H}-4{ }^{`}\right), 3.60\left(1 \mathrm{H}, \mathrm{m}, \mathrm{H}-3^{`}\right)$, $3.72(2 \mathrm{H}, \mathrm{m}, \mathrm{H}-6), 3.84\left(3 \mathrm{H}, \mathrm{s}, \mathrm{O}-\mathrm{CH}_{3}\right), 3.84(1 \mathrm{H}, \mathrm{H}-$ 1'), $4.60(1 \mathrm{H}, \mathrm{d}, \mathrm{J}=7.7 \mathrm{~Hz}, \mathrm{H}-3), 4.73(1 \mathrm{H}, \mathrm{dd}, \mathrm{J}=21.4$ and $11.5 \mathrm{~Hz}, \mathrm{H}-2)^{\prime}, 4.86(1 \mathrm{H}, \mathrm{t}, \mathrm{J}=9.2 \mathrm{~Hz}, \mathrm{H}-1), 5.71$ $(1 \mathrm{H}, \mathrm{s}, \mathrm{H}-7), 6.34\left(1 \mathrm{H}, \mathrm{d}, \mathrm{J}=15.3, \mathrm{H}-2{ }^{\prime}\right), 6.80(1 \mathrm{H}, \mathrm{d}, \mathrm{J}$ $\left.=5.1, \mathrm{H}-8^{\prime \prime}\right), 7.04\left(1 \mathrm{H}, \mathrm{d}, \mathrm{J}=8.4 \mathrm{~Hz}, \mathrm{H}-9^{\prime \prime}\right), 7.63(1 \mathrm{H}$, d, J = 15.3 Hz, H-3“"), 7.76 (1H, s, H-5“).

Extraction, isolation and identification of the active principles from $A$. judaica were done according the methods which adopted by Abbassy et al., (2007) and Abdelgaleil et al., (2007). Dried and powdered aerial parts of A. judaica were hydrodistilled in a Clevengertype apparatus. The resulting essential oil (18 g) was chromatographed on silica gel column using hexane, $2.5 \%$ acetone/hexane, $10 \%$ acetone/hexane and acetone solvent systems. The resulting fractions were concentrated under reduced pressure and examined by

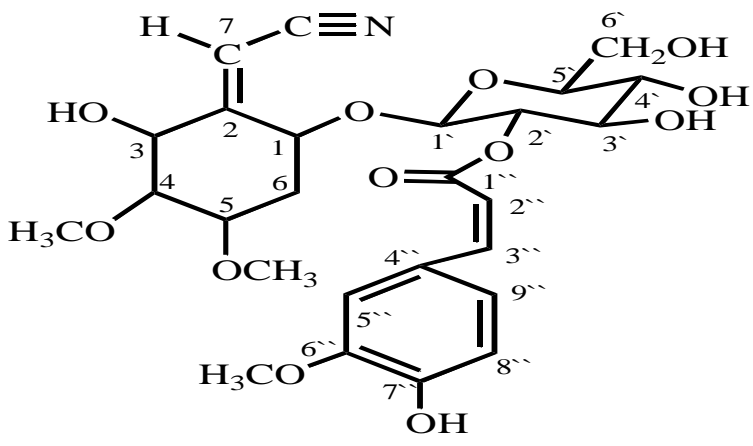

Simmondsin 2-ferulate (2)

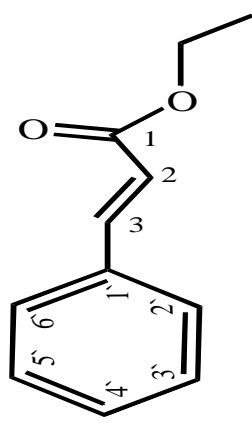

trans-Ethyl cinnamate (4)

Figure1. Chemical structure of isolated compounds from Simmondsia chinensis (1 and 2) and Artemisia judaica(3 and 4) 
TLC to offer two main fractions. The first fraction was further purified on silica gel column eluted with $1 \%$ acetone/hexane to give $2.05 \mathrm{~g}$ of a compound which identified as trans- ethyl cinnamate (4). The second fraction was subjected to silica gel column eluted with chloroform to offer $2.52 \mathrm{~g}$ of a compound which identified as piperitone (3).

Piperitone (3): $\delta{ }^{1} \mathrm{H}$ NMR 0.50 and 0.60 (each $3 \mathrm{H}$, $\mathrm{t}, \mathrm{J}=6.9 \mathrm{~Hz}, \mathrm{Me}-8$ and Me-9), $0.74(1 \mathrm{H}, \mathrm{m}, \mathrm{H}-4 \mathrm{a}), 0.94$ (1H, m H-5), 1.35 (1H, m, H-4b), 1.46 (m, H-6b), 1.59 $(3 \mathrm{H}, \mathrm{d}, \mathrm{J}=11.5 \mathrm{~Hz}, \mathrm{H}-10), 1.66(1 \mathrm{H}, \mathrm{m}, \mathrm{H}-7), 1.99(1 \mathrm{H}$, $\mathrm{m}, \mathrm{H}-6 \mathrm{a})$ and $5.46(1 \mathrm{H}, \mathrm{d}, \mathrm{J}=11.5 \mathrm{~Hz}, \mathrm{H}-3)$.

trans-Ethyl cinnamate (4): $\delta{ }^{1} \mathrm{H}$ NMR $1.06(3 \mathrm{H}, \mathrm{t}$, $\left.\mathrm{J}=6.9 \mathrm{~Hz}, \mathrm{CH}_{2} \underline{\mathrm{CH}}_{3}\right), 3.98\left(2 \mathrm{H}, \mathrm{q}, \mathrm{J}=6.9 \mathrm{~Hz}, \underline{\mathrm{CH}}_{2} \mathrm{CH}_{3}\right)$, $6.18(1 \mathrm{H}, \mathrm{d}, \mathrm{J}=17.6 \mathrm{~Hz}, \mathrm{H}-2), 7.08(3 \mathrm{H}, \mathrm{m}, \mathrm{H}-3$, 4 and 5), $7.23\left(2 \mathrm{H}, \mathrm{m} \mathrm{H}-2{ }^{\prime}\right.$ and $\left.\mathrm{H}-6{ }^{\prime}\right)$ and $7.44(\mathrm{~d}, \mathrm{~J}=19.4$ $\mathrm{Hz}, \mathrm{H}-3)$.

\section{Animals}

White male albino rats (Rattus albinos) were obtained from a breeding culture in the Animal Health Research Centre (Cairo, Egypt). The rats were kept under observation for two weeks before treatments.

5.Toxicological and biochemical effects of the isolated compounds on white male rats.

Two groups of adult's male albino rats $(100-120$ gm) were used in this study. The rats of the first group were given a single oral dose ( 250 or $500 \mathrm{mg} / \mathrm{kg}$ body weight) of each isolated compound in corn oil by stomach tube (single oral dose treatment). The rats of the second group (control group) were administered corn oil without any compounds. All treated rats were observed and mortality percentage was calculated in each treatment. The surviving rats treated with the single oral dose and control treatments were sacrificed two days after treatment and then blood samples collected in clean sterile vials and left till clotting occurred. Serum was collected and centrifuged at $4000 \mathrm{rpm}$ for $10 \mathrm{~min}$. The activities of alkaline phosphates, gamma-glut amyl transferase, lactate dehydrogenase, creatinine phosphokinase enzymes, and the concentrations of testosterone, follicle stimulation hormone and triiodothyronine hormone were determined in the serum.

\subsection{Measurement of Alkaline Phosphatase activity (ALP)}

ALP activity was measured in the serum according to the method reported by Rec (1972) using Diamond Diagnostics Kits. Ten $\mu$ l of each sample was transferred into a test tube containing $1 \mathrm{ml}$ of the working solution. The contents were mixed and the absorbance was measured after $0.5,1,2$ and 3 minutes at $405 \mathrm{~nm}$ using
Jenway 6305 UV / VIS spectrophotometer. The following formula was used to calculate the alkaline phosphatase activity:

Activity $(\mathrm{U} / \mathrm{L})=5454 \mathrm{X} \Delta \mathrm{A}_{405} \mathrm{~nm} / \mathrm{min}$.

\subsection{Determination of gamma- Glutamyl Transferase activity (GGT)}

GGT activity was carried out according to the method reported by Whitfiled et al. (1973) using Liner Chemicals, S. L. Kits. $100 \mu$ l of each serum sample was transferred into a test tube containing $1 \mathrm{ml}$ of the working solution. The resultant mixture was incubated for $1 \mathrm{~min}$ at $30^{\circ} \mathrm{C}$ and the change of absorbance per minute $(\Delta \mathrm{A} / \mathrm{min})$ was measured for a period of 3 minutes at $405 \mathrm{~nm}$ using Jenway 6305 UV/VIS spectrophotometer. The following formula was used to calculate the gamma-glutamyl transferase activity:

Activity $(\mathrm{U} / \mathrm{L})=\Delta \mathrm{A} / \min \mathrm{X} 1111$.

\subsection{Determination of Lactate Dehydrogenase activity (LDH)}

LDH activity was carried out according to the method reported by Rec (1970) using Diamono Diagnostics Kits. $50 \mu \mathrm{l}$ of each serum sample was transferred into a test tube containing $1.5 \mathrm{ml}$ of the working reagent at $25^{\circ} \mathrm{C}$. The absorbance was read after 30 sec. and repeated after 1, 2, 3 minutes at $340 \mathrm{~nm}$ using Jenway 6305 UV/VIS spectrophotometer. The following formula was used to calculate the lactate dehydrogenase activity:

Activity $(\mathrm{U} / \mathrm{L})=4921 \mathrm{X} \Delta \mathrm{A}_{340} \mathrm{~nm} / \mathrm{min}$.

\subsection{Determination of Creatinine Phosphokinase activity (CPK)}

CPK activity was carried out according to the methods reported by Rec (1977) using Diamono Diagnostics Kits. $50 \mu \mathrm{l}$ of each serum sample was transferred into a test tube containing $1.5 \mathrm{ml}$ of the working reagent at $25^{\circ} \mathrm{C}$. The absorbance was read after $30 \mathrm{sec}$. and repeated after $1,2,3$ minutes at $340 \mathrm{~nm}$ using Jenway 6305 UV/VIS spectrophotometer. The following formula was used to calculate the creatinine phosphokinase activity:

Activity $(\mathrm{U} / \mathrm{L})=4921 \mathrm{X} \Delta \mathrm{A} 340 \mathrm{~nm} / \mathrm{min}$.

\subsection{Determination of Follicle-Stimulation hormone (FSH) Concentration}

The concentration of FSH was carried out according to the method reported by Benidrane (1989) using International Immuno Diagnostics Kits. Assay procedure was as following; 1) secure the desired number of coated wells in the holder, 2) dispense $50 \mu 1$ of standard test samples and controls into appropriate wells, 3) dispense $100 \mu \mathrm{l}$ of FSH conjugate reagent into 
each well, 4) thoroughly mix for 30 seconds. It is very important to have completed mixed in this setup, 5) incubate at $37^{\circ} \mathrm{C}$ in a water bath for 1 hour, 6) remove the incubation mixture by flicking plate contents into a waste container, 7) rinse and flick the micro titer wells 5 times with distilled water, 8) strike the wells sharply onto absorbent paper to remove all residual water droplets, 9) dispense $100 \mu 1$ TMB reagent into each well. Gently mix for 5 seconds, 10) incubate at room temperature $\left(22-25^{\circ} \mathrm{C}\right)$ in dark for 30 minutes, 11) stop the reaction by adding $100 \mu$ l of stop solution to each well, 12) gently mix for 30 seconds. It is important to make sure that all the blue color changes to yellow color completely, 13) read the optical density at $450 \mathrm{~nm}$ with a micro titer plate reader within 15 minutes using ELISA, GmbH model Jupiter.

\subsection{Determination of Testosterone hormone concentration}

Testosterone hormone concentration was carried out according to the method reported by Turkes (1979) using International Immune Diagnostics Kits. Similar procedure of FSH was followed except for adding testosterone conjugate reagent and incubation times of some steps were varied.

\subsection{Determination of Triiodothyronine hormone concentration}

(T3)

Triiodothyronine (T3) hormone concentration was carried out according to the method reported by Cavalieri and Rapoport (1977) using International Immuno Diagnostics Kits. Similar procedure of FSH was followed except for adding T3 conjugate reagent and incubation times of some steps were varied.

\subsection{Statistical analysis}

Enzyme activities and hormone concentrations were subjected to one-way analysis of variance (ANOVA) followed by Student-Newman-Keuls test (Cohort software Inc., 1985) to determine the significant differences among mean values at the probability level of 0.05 .

\section{RESULTS AND DISCUSSIONS}

1. Isolation and structure determination of active principles

The chloroform extract of $S$. chinensis seeds was fractionated on silica gel column chromatography and the most active fractions were further purified on a silica gel column followed by recrystallization to give the two glucosides; simmondsin (1) and simmondisn 2`-ferulate (2). In addition, a monoterpenoid piperitone (3) and a phenylpropanoid trans-ethyl cinnamate (4) were isolated from A. judaica essential oil by repeated silica gel column chromatography. The chemical structures of the isolated compounds (1-4) were elucidated by using spectroscopic methods, including UV, IR, ${ }^{1} \mathrm{H}$ NMR,${ }^{13} \mathrm{C}$ NMR and MS. Extensive studies of spectroscopic data of the isolated compounds allowed us to confirm the four isolated compounds as simmondsin (1), simmondsin 2-ferulate (2), piperitone (3) and transethyl cinnamate (4). The two glucosides $\mathbf{1}$ and $\mathbf{2}$ isolated from $S$. chinensis have been reported before as main components of jojoba seeds (Van Boven et al., 1994 and Van Boven et al., 1995). On the other hand, the two isolated compounds $\mathbf{3}$ and $\mathbf{4}$ represented the major constituents of the oil of A. judaica as stated by ElMassry et al., 2002.

\section{Toxic and biochemical effects of the isolated} compounds

Oral administration of single oral doses each of 250 or $500 \mathrm{mg} / \mathrm{kg}$ of each compound did not show any sings of toxicity or mortality in treated rats after two days of treatment.

Results in Table 1 show that oral administration of single doses of simmondsin, simmondsin $2^{\prime}$-ferulate, piperitone and trans-ethyl cinnamate to rats revealed

Table 1. In vivo effect of isolated secondary plant metabolites on some enzyme activities in the blood serum of treated rats

\begin{tabular}{|c|c|c|c|c|c|}
\hline \multicolumn{2}{|c|}{$\begin{array}{c}\text { Compound / Treatment } \\
(\mathbf{m g} / \mathrm{kg})\end{array}$} & $\begin{array}{c}\text { ALP } \\
(\mathbf{U} / \mathbf{L}) \\
\end{array}$ & $\begin{array}{l}\text { GGT } \\
\text { (U/L) }\end{array}$ & $\begin{array}{c}\text { LDH } \\
\text { (U/L) }\end{array}$ & $\begin{array}{c}\text { CPK } \\
(\mathbf{U} / \mathbf{L}) \\
\end{array}$ \\
\hline Control & & $146.9 \pm 0.25^{\mathrm{e}}$ & $11.6 \pm 0.25^{\mathrm{bc}}$ & $225.2 \pm 0.36^{\mathrm{e}}$ & $82.6 \pm 0.25^{\mathrm{e}}$ \\
\hline \multirow{2}{*}{ Simmondsin } & 250 & $144.0 \pm 0.21^{\mathrm{g}}$ & $11.5 \pm 0.15^{\mathrm{c}}$ & $222.9 \pm 0.31^{\mathrm{f}}$ & $74.0 \pm 0.35^{\mathrm{t}}$ \\
\hline & 500 & $149.0 \pm 0.20^{\mathrm{d}}$ & $11.8 \pm 0.36^{\mathrm{bc}}$ & $219.4 \pm 0.25^{\mathrm{n}}$ & $72.7 \pm 0.35^{\mathrm{g}}$ \\
\hline \multirow{2}{*}{$\begin{array}{l}\text { Simmondsin 2- } \\
\text { ferulate }\end{array}$} & 250 & $143.7 \pm 0.36^{\mathrm{g}}$ & $11.4 \pm 0.25^{\mathrm{c}}$ & $223.0 \pm 0.35^{\mathrm{f}}$ & $74.1 \pm 0.20^{f}$ \\
\hline & 500 & $145.5 \pm 0.35^{\mathrm{t}}$ & $11.6 \pm 0.15^{\mathrm{bc}}$ & $220.1 \pm 0.40^{\mathrm{g}}$ & $73.9 \pm 0.20^{\mathrm{t}}$ \\
\hline \multirow{2}{*}{ Piperitone } & 250 & $147.7 \pm 0.20^{\mathrm{e}}$ & $11.8 \pm 0.15^{\mathrm{bc}}$ & $225.9 \pm 0.20^{\mathrm{d}}$ & $86.8 \pm 0.35^{\mathrm{d}}$ \\
\hline & 500 & $151.9 \pm 0.31^{\mathrm{b}}$ & $12.3 \pm 0.37^{\mathrm{ab}}$ & $230.1 \pm 0.10^{\mathrm{b}}$ & $89.5 \pm 0.15^{\mathrm{b}}$ \\
\hline \multirow{2}{*}{$\begin{array}{l}\text { trans-Ethyl } \\
\text { cinnamate }\end{array}$} & 250 & $150.3 \pm 0.25^{\mathrm{c}}$ & $12.3 \pm 0.25^{\mathrm{ab}}$ & $227.3 \pm 0.20^{\mathrm{c}}$ & $88.2 \pm 0.20^{\mathrm{c}}$ \\
\hline & 500 & $158.2 \pm 0.64^{\mathrm{a}}$ & $12.8 \pm 0.36^{\mathrm{a}}$ & $234.1 \pm 0.35^{\mathrm{a}}$ & $92.1 \pm 0.10^{\mathrm{a}}$ \\
\hline
\end{tabular}

ALP = alkaline phosphatase; GGT = gamma-glutamyl transferase; $\mathrm{LDH}=$ lactate dehydrogenase; $\mathrm{CPK}=$ creatinine phosphokinase.

Data are expressed as means \pm S.D. from experiments with three replicates.

Means within a column sharing the same letter are not significantly different at the 0.05 probability level. 
Table 2. In vivo effect of isolated secondary plants metabolites on some hormone concentrations in the blood serum of treated rats

\begin{tabular}{lcccc}
\hline $\begin{array}{l}\text { Compound/ Treatment } \\
(\mathbf{m g} / \mathbf{~ k g})\end{array}$ & $\begin{array}{c}\text { T3 } \\
(\mathbf{n g} / \mathbf{d L})\end{array}$ & $\begin{array}{c}\text { FSH } \\
(\mathbf{m U} / \mathbf{m L})\end{array}$ & $\begin{array}{c}\text { Testosterone } \\
(\mathbf{n g} / \mathbf{m L})\end{array}$ \\
\hline Control & $225.1 \pm 0.95^{\mathrm{c}}$ & $4.24 \pm 0.02^{\mathrm{a}}$ & $3.72 \pm 0.03^{\mathrm{a}}$ \\
Simmondsin & 250 & $220.1 \pm 2.05^{\mathrm{a}}$ & $3.99 \pm 0.20^{\mathrm{b}}$ & $3.63 \pm 0.02^{\mathrm{b}}$ \\
& 500 & $118.4 \pm 0.45^{\mathrm{e}}$ & $3.85 \pm 0.15^{\mathrm{b}}$ & $3.58 \pm 0.04^{\mathrm{b}}$ \\
Simmondsin 2-ferulate & 250 & $220.6 \pm 0.70^{\mathrm{d}}$ & $4.00 \pm 0.06^{\mathrm{b}}$ & $3.65 \pm 0.05^{\mathrm{b}}$ \\
& 500 & $119.8 \pm 0.60^{\mathrm{e}}$ & $3.87 \pm 0.10^{\mathrm{b}}$ & $3.61 \pm 0.03^{\mathrm{b}}$ \\
Piperitone & 250 & $225.5 \pm 0.60^{\mathrm{c}}$ & $3.45 \pm 0.01^{\mathrm{c}}$ & $3.74 \pm 0.03^{\mathrm{a}}$ \\
& 500 & $229.0 \pm 0.35^{\mathrm{b}}$ & $3.27 \pm 0.04^{\mathrm{a}}$ & $3.79 \pm 0.02^{\mathrm{a}}$ \\
trans-Ethyl cinnamate & 250 & $225.8 \pm 0.40^{\mathrm{c}}$ & $4.02 \pm 0.03^{\mathrm{b}}$ & $3.73 \pm 0.04^{\mathrm{a}}$ \\
\hline
\end{tabular}

$\mathrm{FSH}=$ follicle stimulation hormone; $\mathrm{T} 3$ = triiodothyronine hormone.

Data are expressed as means \pm S.D. from experiments with three replicates.

Means within a column sharing the same letter are not significantly different at the 0.05 probability level

varied effects on the activity of serum alkaline phosphatase enzymes (ALP). Simmondsin 2'-ferulate displayed significant decrease in the activity of enzymes at the two tested doses compared with control. Simmondsin caused decrease in the activity of the enzymes at $250 \mathrm{mg} / \mathrm{kg}$ while it caused increase in the enzymes activity at $500 \mathrm{mg} / \mathrm{kg}$. The activity of enzymes was increased when rats treated with piperitone and trans-ethyl cinnamate at 250 and $500 \mathrm{mg} / \mathrm{kg}$. All of the tested compounds had no significant effect on the activity of gamma-glutamyl transferase (GGT) except for trans-ethyl cinnamate which increased the enzyme activity at $500 \mathrm{mg} / \mathrm{kg}$.

On the other hand, simmondsin and simmondsin $2^{\prime}-$ ferulate displayed significant decrease in the activity of both lactate dehydrogenase (LDH) and creatinine phosphokinase (CPK) enzymes at the two tested doses, while piperitone and trans-ethyl cinnamate caused increase in the activity of the tested enzymes. The increase or decrease of the activity of each enzyme was more pronounced in the rats given the high dose of each compound $(500 \mathrm{mg} / \mathrm{kg})$ than that of the rats given 250 $\mathrm{mg} / \mathrm{kg}$ body weight. It has been reported that the extracts of and latex of Calotropis procera as well as the isolated compounds uscharin and voruscharin caused elevation or reduction of the activities of liver enzymes (El-Sheikh et al., 1991; Basu et al., 1992; El-Sebae, 1996).

Results in Table 2 revealed that oral administration of simmondsin and simmondsin $2^{\prime}$-ferulate caused significant decrease in the concentration of triiodothyronine hormone (T3) at the two tested doses while piperitone and trans-ethyl cinnamate caused slight increase of hormone concentration at $250 \mathrm{mg} / \mathrm{kg}$ and significant increase at $500 \mathrm{mg} / \mathrm{kg}$. All of the tested compounds lowered follicle stimulation hormone (FSH) concentration without significant differences between treatments. The tested compounds simmondsin and simmondsin decreased the concentration of testosterone hormone while piperitone and trans-ethyl cinnamate elevated the concentration of the hormone. Again the higher dose of each botanical compound $(500 \mathrm{mg} / \mathrm{kg})$ caused higher decrease or increase in the concentration of each hormone than the lower dose $(250 \mathrm{mg} / \mathrm{kg}$ body weight).

From a standpoint of pesticides chemistry and toxicology the most important aspect in the search for new pest control chemical is to find compounds which are selectivity toxic or biologically active against pest and have low toxicity to mammals. From such standpoint, the more promising pesticidal secondary plant metabolites in this work, simmondsin; simmondsin $2^{\prime}$-ferulate of S. chinensis and piperitone and trans-ethyl cinnamate of $A$. judaica volatile oil did not show any mortality or any signs of toxicity in rats given single oral doses from each compound up to $500 \mathrm{mg} / \mathrm{kg}$ body weight. However, the biochemical results show that dosing rats with a single oral dose either 250 or 500 $\mathrm{mg} / \mathrm{kg}$ body weight of each botanical compound did cause significant effect on the activities of ALP, CPK, LDH enzymes and on concentrations of FSH, T3, Testosterone in the serum of treated rats.

\section{REFERENCES}

Abbassy, M.A.; Belal, A.H.; Abdelgaleil, S.A.M; Abdel Rasoul, M.A.A. (2006). Insecticidal and antifeedant activities of two glucosides isolated from the seeds of Simmondsia chinensis (link) Schneider against cotton leafworm, Spodoptera littoralis (Boisd.). J. Pest Cont. Environm. Sci. 14, 271-282.

Abbassy, M.A.; Abdelgaleil, S.A.M; Belal, A.H.; Abdel Rasoul, M.A.A. (2007). Insecticidal, antifeedant and antifungal activities of two glucosides isolated from the seeds of Simmondsia chinensis (link). Ind. Crops Prod. 26, 345-350.

Abdelgaleil, S.A.M.; Abbassy, M.A.; Belal, A.H.; Abdel Rasoul, M.A.A. (2007). Evaluation of molluscicidal properties of extracts and active principles from two Egyptian plants against the terrestrial snail, Eobania vermiculata. J. Pest Cont. Environm. Sci. 15, 101-112. 
Basu, A.; Sen, T.; Ray, N. R.; Chaudhuri, N. K. A. (1992). Hepatoprotective effects of Calotropis procera root extract on expermental liver damage in animals. Fitoterapia, 63: 507-514.

Benidrane, M.E. (1989). Production of monoclonal antibodies complementary to an antibody-antigen complex. J. Immunol. Methods. 111:189.

Cavalieri, R.R.; Rapoport, B. (1977). Impaired peripheral conversion of thyroxine to triiodothyronine. Ann. Rev. Med., 28:57-65.

Cohort Software Inc., (1985). Costat User's Manual. Version 3. Cohort Tucson, Arizona, USA.

El-Massry, K.F.; El-Ghorab, A.H.; Farouk, A. (2002). Antioxidant activity and volatile components of Egyptian Artemisia judaica L. Food Chem. 79:331-336.

Gonzalez-Coloma A.; Gutierrez C.; Cabrera R.; Reina M. (1997). Silphinene Derivatives: Their effects and modes of action on Colorado potato beetle. J. Agric. Food Chem. 45: 946-950.

El-Sebae, M. A. (1996). Evaluation of the efficacy of some new compounds as pesticidal activities of some cardenolides isolated from Calotropis procera plant. Alex. Univ. Faculty of Agriculure, Ph.D.

El-Sheikh, H. A.; Ali, B. H.; Homeida, A. M.; Hassan, T.; Idris, O. F.; Hapke, H. J. (1991). The activities of drug-metabolizing ezymes in goats treated orally with the latex of Calotropis procera and the influence of dieldrin pre-treatment. J. Com. Pathol., 104: 257-268.
Jacobson M. (1989). Botanical Pesticides Past, Present and Future. In Insecticides of Plant Origin; Arnason JT, Philogene BJR, Morand P, Eds; ACS Symposium Series 387, Washington, DC; pp 95-109.

Rec, G.S.C. (1970). J.Clin.Chem.Clin. Biochem. 8: 658.

Rec. G.S.C. (1972). J. Clin. Chem. Clin. Biochem. 10:182.

Rec, G.S.C. (1977). J.Clin.Chem.Clin. Biochem. 15: 255.

Shrestha, M. K.; Peri, I.; Smirnoff, P.; Birk, Y.; Goldhirsh, A. G. (2002). Jojoba seed meal proteins associated with proteolytic and protease inhibitory activities. J. Agric. Food Chem. 50: 5670-5675.

Singh M.; Khokhar S.; Malik S.; Singh R. (1997). Evaluation of neem (Azadirachta indica A. Juss) extracts against American bollworm, Helicoverpa armigera (Hubner). J.Agric. Food Chem. 45, 3262-3268.

Turkes, A. (1979) .J. Endocrinol. 81(2):165.

Van Boven, M.; Toppet, S.; Cokelaere, M.; Daenens, P. (1994). Isolation and structural indentifection of a new simmondsin ferulate from jojoba meal. J. Agric. Food Chem. 42: 1118-1121.

Van Boven, M.; Daenens, P. Cokelaere, M. (1995). New simmondsin 2 ferulates from jojoba meal. J. Agric. Food Chem. 43: 1193-1197.

Whitifield, J.B.; Moss, D. W.; Neale, G.; Orme, M. Breckenridge, A. (1973). J. Brit. Med., 1:136. 


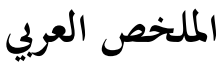

\section{التأثيرات السامة و البيوكيميائية لأربع مركبات طبيعية معزولة من نباتى الجوجوبا والشيح على فئران التجارب البيضاء \\ مصطفى عبد اللطيف عباسى، سمير عبد العظيم مُحَّمَ عبد الجليل، عبد السلام حلمى بلال، منى عبد النبعبد الرسول}

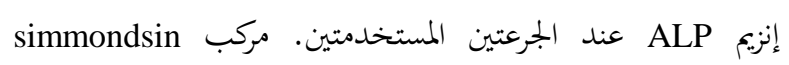

سسب خفض فن نشاط الإنزيم عند الجرعة 250 مجم/كجم وزيادة

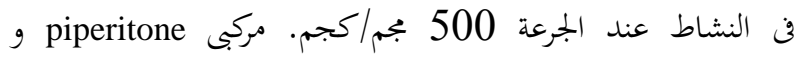
trans-ethyl cinnamate أظهرا زيادة في نشاط الإنزيم عند الجرعتين

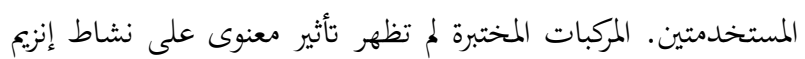
500 عد 1 مركب trans-ethyl cinnamate عند الجرعة GGT مجم/كجم. مركبى simmondsin 2〕ferulate simmondsin أحدثا خفض معنوى في نشاط إنزيمى

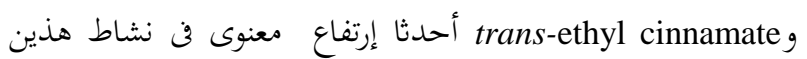
الإنزيمين. المركبات المختبرة خفضت تركيز هرمونFSH عند الجرعات

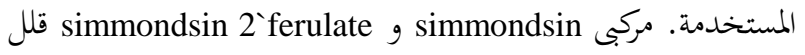

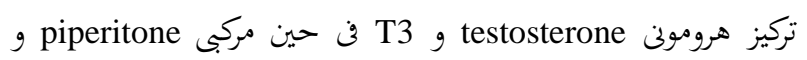
trans-ethyl cinnamate
تم عزل أربع مركبات طبيعية: أثنين من نبات الجوجوبا هما simmondsin و وأثنين من نبات الشيح هما trans-ethyl cinnamate و تم إعطاء الفئران جرعة وكن واحدة عن طريق الفم وهى إما 250 بجم/كجم أو 500 مجم/كجم

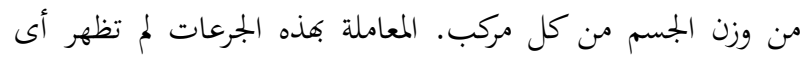

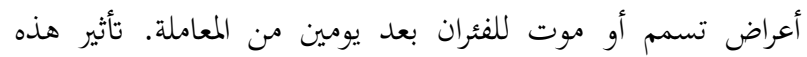
alkaline phosphatase ( ALP ) المركبات على نشاط إنزيمات lactate g gamma-glutamyl transferase (GGT)و creatinine phosphokinase (CPK) g dehydrogenase (LDH) وكذلك تركيز هورمونات testosterone و و triiodothyronine hormone (T3) و في سيرم hormone (FSH)

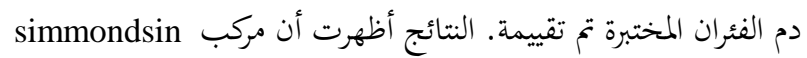
2〕ferulate سبب خفض معنوى في نشاط 